\title{
Personal Values: The foundation of the relationship in the remarriage with the ex-spouse
}

\author{
Valores Pessoais: o alicerce do relacionamento no recasamento com o \\ ex-cônjuge
}

Maria Ignez Carneiro de Azevedo LIMEIRA' 1 (D) 0000-0001-7279-3394

Terezinha FÉRES-CARNEIRO' ${ }^{1}$ (D) 0000-0002-0564-7810

\begin{abstract}
The present study, part of a larger investigation on remarriage with the ex-spouse, aims to examine the effects of personal values on the reconstruction of a marital relationship with the former spouse. A qualitative study was carried out, where 12 individuals of 12 different couples from Rio de Janeiro's middle classes population, were interviewed - heterosexuals, married to the ex-spouse, with children. The content analysis method was used to analyze the results, and the personal values category and its subcategories, marriage conception and religious beliefs were discussed. Findings indicate that personal values are part of the foundation that underpins the chosen direction for the reconstruction of these relationships. As they followed the paths they chose, the spouses, aware of what they valued most and the investments, reported to feel pleasant sensations, as peace, harmony and security that facilitated this process consolidation.
\end{abstract}

Keywords: Ex-spouse; Religious beliefs; Remarriage; Value.

\section{Resumo}

O presente estudo, parte de uma investigação mais ampla sobre o recasamento com o ex-cônjuge, objetiva examinar os efeitos dos valores pessoais na reconstrução do relacionamento conjugal com o ex-cônjuge. Realizou-se uma pesquisa qualitativa. Foram entrevistados 12 membros de 12 casais distintos, heterossexuais, de camadas médias da população do Rio de Janeiro, casados com o ex-cônjuge, com filhos em comum. Para análise dos resultados utilizou-se o método de análise de conteúdo, sendo discutida a categoria valores pessoais e suas subcategorias: concepção de casamento e

\footnotetext{
$\nabla \nabla \nabla \nabla$
}

${ }^{1}$ Pontifícia Universidade Católica do Rio de Janeiro, Centro de Teologia e Ciências Humanas, Pós-Graduação em Psicologia. Rua Marquês de São Vicente, 225, Gávea, 22451-900, Rio de Janeiro, RJ, Brasil. Correspondência para/Correspondence to: M.I.C.A. LIMEIRA. E-mail: <ignezrj1@gmail.com>.

Article based on the thesis of M. I. C. A. LIMEIRA, entitled "Recasamento com o ex-cônjuge: um processo de reconstrução conjunta da relação conjugal." Pontifícia Universidade Católica do Rio de Janeiro, 2018.

Como citar esse artigo/How to cite this article

Limeira, M. I. C. A., \& Féres-Carneiro, T. (2019). Personal values: The foundation of the relationship in the remarriage with the exspouse. Estudos de Psicologia (Campinas), 36, e180106. http://dx.doi.org/10.1590/1982-0275201936el80106 
crenças religiosas. Constatou-se que os valores pessoais fazem parte do alicerce que sustenta a direção escolhida para a reconstrução destes relacionamentos. Ao trilharem os caminhos que decidiram tomar, os parceiros, conscientes do que mais valorizavam e dos investimentos associados, relataram experimentar sensações agradáveis, como paz, harmonia e segurança, que facilitaram a consolidação deste processo.

Palavras-chave: Ex-cônjuge; Crenças religiosas; Recasamento; Valores.

People's values and beliefs influence their choices, decisions, attitudes, and relational behaviors (Gomes, Gouveia, Silva Júnior, Coutinho, \& Campos, 2013; Willoughby, Hall, \& Goff, 2015a; Willoughby, Hall, \& Luczak, 2015b). The beliefs describe the meaning or thought that one assumes as a truth (Willoughby et al., 2015b). As for the values, according to Maslow (1943), they are closely linked to the basic needs, intrinsic to the structure of the self and dependent on individual history. For this researcher, higher motivations such as love and justice are as basic to man as thirst - they are only less urgent, and show that there is a considerable relationship of dependence on the environment, since they can only be satisfied by other people. In difficult times, the most important reasons for remaining in a marriage are those related to personal values and beliefs (Norgren, Souza, Kaslow, Hammerschmidt, \& Sharlin, 2004).

Gouveia (2003) suggested a list of twenty-four values representing the content of basic needs, starting from the premise that the nature of man is essentially good (Maslow, 1943). Because they are largely a consequence of socialization, values are adopted by people through logical or moral arguments that justify why they are desirable. According to Gouveia (2003), values permeate situations and ideas; are latent constructs with two main functions - guiding an individual's actions and expressing their needs. When combined, these functions generate six value sub-functions: existence, normative, supra-personal, realization, experimentation, and interactional.

In analyzing the most important reasons to marry according to people, Zordan, Falcke, and Wagner (2009) found that these are related to the same factors that stimulate the maintenance of the marital relationship. Among the values mentioned, most of the people chose aspects related to love, family, children and religiosity. For Gomes et al. (2013), values are more prevalent attributes in choosing the ideal partner than personality traits.

The results of the study by Borges and Magalhães (2013), whose objective was to analyze the life projects of older (between 63 and 69 years-old) and younger (between 27 and 34 years-old) adults, showed that there are currently two different concepts of family. Older adults presented a traditional concept in which the family begins with the marriage, which is expected to last. Younger adults did not seem to believe in long-term relationships, and their primary focus on forming a family was the idea of having children. However, there was some contradiction to also valuing some questions of the traditional model related to the role of men in the family. For Borges, Magalhães, and Féres-Carneiro (2014), the younger generation wants to have "wings and roots", because freedom is highly valued, but the need for social belonging remains, coupled with the great idealization of a loving relationship. This illustrates the contemporary challenge of seeking a balance between individuality and conjugality in marriage.

In the study by Fonseca and Duarte (2014), participants aged 26-37 expected marriage to be lifelong - a vow only broken in extreme cases - and had a view that their children would come as a consequence of greater intimacy and time together. In addition, a less perfectionist mentality of conjugal life has been perceived, in which both give in, accept the partner and privilege the well-being of each other, without feeling overruled. In view of this, the authors affirm that, despite the proliferation of new family configurations, the ideal of a stable marriage based on the socialization process and family 2 experiences still subsists. 
According to Hall (2006), insofar as the meaning that people give to marriage has an impact on how they behave in relation to it, knowing the beliefs underlying the marital relationship becomes a critical factor in understanding the interactions between the partners. His research has shown that marriage can be conceptualized, along a continuum, in five dimensions of interrelated and polarized beliefs. They are: (a) a special status relationship (the most satisfactory of all) x neutral relationship ("a piece of paper"); (b) self-realization (all that can be attained for oneself) $\mathrm{x}$ responsibility (above individual achievement); (c) unit (single identity) x individuality (little restriction of autonomy); (d) romanticism ("soul mates", complete acceptance, without demanding a lot of effort) x pragmatism (practical system of exchanges), and (e) hierarchical roles (commonly associated with the individual's sex) x parallel roles (equity, companionship).

Willoughby et al. (2015b) presented the theory of the marital paradigm, in which marital beliefs have six distinct dimensions in relation to getting married and being married, which are mutually reinforcing. The three dimensions related to "being married" are: (a) marital centrality, linked to the size of the investment in the marital role and how central the role of the spouse is in his/her life compared to that of friends, relatives and the individual's career; (b) marital permanence, includes beliefs about the commitment to marriage and under what circumstances it may be broken, and (c) marital processes, refers to what is expected of issues such as work-life balance. The research by Willoughby et al. (2015a) showed that women and young adults with a high level of religiosity are more likely to adopt beliefs of marital centrality. In addition, the behavior of these individuals was significantly moderated by the high levels of such beliefs and religiosity, suggesting a link between religious beliefs, marital beliefs and behaviors.

The different dimensions of religious beliefs have been pointed out by several authors as encouraging for maintaining the commitment to marriage (Alves-Silva, Scorsolini-Comin, \& dos Santos, 2016; Fonseca \& Duarte, 2014; Norgren et al., 2004). Burdette, Ellison, Sherkat, and Gore (2007) found that being affiliated with some religion is related to reducing the likelihood of marital infidelity, with the exception of Mormons, Jehovah's Witnesses, and non-Christian religions. The results suggested that the greater frequency of participation in religious meetings and the theological view that the Bible is literally the word of God, and not only a metaphor inspired by Him, seem to explain this effect. The findings of Ellison, Wolfinger, and Ramos-Wada (2013) have indicated that religious activities, institutional or not, can generate traditional ideas about family. In their study, the literal view of the Bible was associated with three attitudes: (a) marriage is an unbreakable vow before God; (b) people should not divorce if they feel they do not love each other, and (c) cohabiting is morally wrong.

The research by Ciscon-Evangelista and Menandro (2011) pointed out that the question of the indissolubility of marriage for Protestant couples contributed to their attempts to maintain harmony and resolve their conflicts through dialogue, since divorce was not an option to be considered. By "converting" to the new religious view, the participants in that study reformulated their values, by identifying themselves with the other members of the group and sharing their beliefs, which generated transformations in their worldview, daily practices and relationships. According to the authors, the possible differences between the spouses were minimized by something both of them chose as more valuable - the religious principles coming from the same source considered crucial.

In a study with Christian, Jewish, and Islamic couples, Dollahite, Hawkins, and Parr (2012) found that, for these couples, marriage is a sacred institution of which God is a part, greater than the self, the couple or family, and which transcends the opinion of society in general. It is the synergistic union of two persons, which allows "the whole to be greater than the sum of the parts," in which there must be a sincere commitment to the marital alliance, throughout life. Such a "powerful idea" helped them to focus on themselves and redirect them to each other and to the relationship, bringing a deeper meaning to marriage - earnest, altruistic promises that cannot be broken. 
The support of a religious community and religiosity in general (practices and trust in religious beliefs) were associated with greater marital commitment (Olson, Goddard, \& Marshall, 2013). Goodman, Dollahite, Marks, and Layton's (2013) survey with 184 religious couples showed that the inclusion of these people into a community of faith and the adoption of specific beliefs, practices, and principles become the driving force behind their attitudes. Among the beliefs are: (a) marriage is a distinct relationship from all others and defined by God; (b) God is an effective part of the couple's relationship; (c) such bond is indissoluble, and (d) the challenges have a divine purpose of development and bringing the spouses closer together and God, who helps them in the solution of these challenges. Among the practices and principles are the study of the scriptures, rituals, spiritual counseling, repentance, and forgiveness.

The study by Olson, Marshall, Goddard, and Schramm (2015) has shown that religiosity protects marriage against risk factors, such as stressful relationships or previous divorces, and that there is a significant positive relationship between indicators of religiosity and marital satisfaction. Spouses who pray and go together to religious meetings and who believe that God is present at their marriages are more likely to engage in mutual behaviors of conjugal generosity (Wilcox \& Dew, 2016). When partners consider God to be a transcendent moral authority, they perceive Him as a model and personal provider, with whom they build a close and profound relationship by serving Him, obeying Him, being favored by Him, and identifying with Him. Thus, a symbolic structure is formed in which the vertical relationship with God is integrated into a horizontal ethics of care between the spouses, leading the relationship to be influenced by this relation of authority. In this way, unity and commitment are reinforced by relational dynamics in which partners change behaviors by having God's love as a pattern of strengthening marital bonds (Shichida, Dollahite, \& Carroll, 2015).

Thus, it is perceived that people's values and beliefs permeate the environment in which conjugality is being built over time. This time has a transformative role for the post-divorce adjustment, considered as a process of development that requires several transitions and changes, from grieving the loss of their marriage to the adaptation to a new life (Lloyd, Sailor, \& Carney, 2014). Even if it is a reconciliation, it is a 'new life' and, in this scenario, it is relevant to analyze the role of values and beliefs in order to understand these choices more deeply. Thus, the purpose of this study is to examine the effects of personal values on the reconstruction of the marital relationship in the remarriage with the ex-spouse.

\section{Method}

\section{Participants}

Field research was carried out with 12 individuals of 12 distinct couples (six men and six women), who were indications originating from the researcher's personal and professional network, constituting a convenience sample. Both members of each couple were not interviewed as the scope of the study was not intended to investigate the conjugal dynamics of reconciliation, but what led, from the point of view of one of the couple's members, to remarriage with the same spouse. The number of participants was determined by the saturation provoked by the repetition of the themes (Minayo, 2017).

Upon receiving the indications, the researcher, through an initial telephone conversation, selected those who met the following criteria: belonging to the middle strata of the population of the city of Rio de Janeiro, heterosexuals, remarried with the ex-spouse at the time of the research for at least 1 year, and with at least one child. In addition, participants would need to have had a first marriage of at least 2 years; and would have to be separated or divorced for at least 6 months, living in different houses. No civil registration was required for the couple to be considered as married or separated. Table 1 presents a description of the 4 participants' profiles and the duration of their marital transitions. 


\begin{tabular}{|c|c|c|c|c|c|}
\hline \multirow[b]{2}{*}{ Spouse } & \multirow[b]{2}{*}{ Age } & \multirow[b]{2}{*}{ Religion } & \multicolumn{3}{|c|}{ Duration (years) } \\
\hline & & & First marriage & Separation & $\begin{array}{l}\text { Remarriage (at the } \\
\text { moment of interview) }\end{array}$ \\
\hline F1 & 59 & Catholic & 5 & 13 & 18 \\
\hline F2 & 39 & Catholic & 7 & 2 & 3 \\
\hline F3 & 36 & Protestant & 5 & 0.75 & 8 \\
\hline F4 & 55 & None & 17 & 16 & 1 \\
\hline F5 & 45 & Catholic & 10 & $1^{1 / 2}$ & 8 \\
\hline F6 & 65 & Buddhist & 11 & 15 & 18 \\
\hline M1 & 55 & Protestant & 5 & 1 & 20 \\
\hline M2 & 68 & Catholic & 15 & 12 & 22 \\
\hline M3 & 63 & Protestant & 22 & $4^{1 / 2}$ & 16 \\
\hline M4 & 76 & Protestant & 25 & 20 & 6 \\
\hline M5 & 45 & Catholic & 12 & 1 & 2 \\
\hline M6 & 66 & Catholic & 7 & 25 & $1^{1 / 2}$ \\
\hline
\end{tabular}

Note: F: Female; M: Male.

\section{Instrument}

Individual interviews with a semi-structured script were recorded in audio and, later, fully transcribed. The script was formulated based on the existing literature regarding the subject and focused on the following thematic axes: meanings and expectations about marriage; issues related to parenting and children's influence on separation and remarriage; events with major repercussions for separation; differences and similarities between remarriage and first marriage; experiences and attitudes after separation as to work, finances, relationships, among others, and losses and gains from separation and remarriage.

\section{Procedures}

The research project was approved by the Ethics Committee (Procedure No. 2016-27) of the institution where it was developed. The interviews lasted between one and two hours and the place, date and time were scheduled according to the availability of the participants. All of them signed an Informed Consent Term, authorizing the dissemination of the results in classes, in research and through academic publications, and were informed that their identities, as well as the identity of their family members, would be safeguarded.

\section{Data analysis}

For the analysis of the data obtained in the interviews, the content analysis method was used, in its categorical aspect, as proposed by Bardin (2011). The method allows the inference of knowledge regarding the conditions of production and reception of the messages, that is, knowing what is behind the words. It is based on the articulation between the description and the analysis of the texts, and the factors that determined these characteristics, deduced through logic. Thus, the reports considered relevant to the discussions were grouped by similarity of meaning and related, among themselves, until the thematic categories emerged from the interviews. 


\section{Results and Discussion}

The present study presents part of the results of a more comprehensive research that sought to understand, from the participants' reports, the main factors that contribute to the reconstruction of marital relationship in the remarriage of an individual with the ex-spouse. For the presentation of the results, the participants will be named $\mathrm{F}$ (female) and $\mathrm{M}$ (male), numbered from 1 to 6 , having their age and remarriage time indicated in years (r.y.).

It was noticed that personal values permeated the participants' accounts in explaining what they thought about marriage in several aspects. Some of the interviewees also included, specifically, issues related to the religious aspect. Thus, to achieve the objectives of this study, i.e. examine the effect of personal values in the reconstruction of marital relationship in the remarriage with the former spouse, the analysis category personal values and its two subcategories will be discussed.

\section{Personal values}

In this study, personal values are understood as deep-rooted internal rules that guide the lives of people and lead them to make decisions and behave in a certain way, because they understand that it is the best thing to do, thus exposing consciousness (Barret, 2000).

In this sense, there are many studies on the different relational processes associated with the meaning of marriage and religious beliefs, but none was found focusing on cases of reconciliation after permanently severing the relationship. In this way, this category explores how personal values, associated with the individual meaning of marriage, have repercussions on remarriage with the same spouse, and are then deployed in: conception of marriage and religious beliefs.

\section{- Wedding Conception}

In describing the meaning of marriage, all participants expressed values that seemed to be related to the decision-making process that led them to reconciliation with the former spouse, as these concepts came to the surface as they reflected, further in their stories, on what was most important to them. To illustrate this, the narratives of this subcategory show two moments of the interview for each participant: the first, when they explain what they mean by marriage; and the second, what they thought or reported that they felt when they were reconciled.

Marriage is the sum of love, affection, it is ... partnership, friendship, and ... how can I put it? When you see the person and you see that person professionally, and that you're charmed with what you see. ... And she returned with the expectation of work. Then I began to weigh things in, what I had before, a family, and what I had then. So what I had before weighed a lot more, right? Of the several girls you met, you married one. So, this selection process needs to be valued (M1, 55 years-old, 18 r.y.).

Marriage to me is what I'm living right now, you know? It is a thing of wanting to be together, bonding, a thing of yours. We want to have something that we "own" a part of, can you understand me, we're kind of the creators of that. I created a little nucleus there, made up of a woman, son, and took pleasure in it. ... It is a legacy that I will leave. It's a building that I feel like one of the ... pillars, since it came from me, from her, that the children came, and from that ... (M6, 66 years-old, 1.6 r.y.) 
It's ... live love, grow together, right? To form the family. ... A second chance at life so that I can, so that I can relive the ... formation again, right? Because I have beautiful children. So, I think that remarrying was in this sense of redeeming, to redeem, to redeem, right? And being with the person that is ... that I deeply love, right? The feeling that fills me is peace. It's as if now I'm doing the right thing. Because in other relationships, no matter how intense they were, I had no peace. And now I have peace (F6, 65 years-old, 18 r.y.).

Expressions such as 'now I'm doing the right thing', 'a legacy', or 'this selection process needs to be valued' show the strength of personal values for the re-choosing of partners (Gomes et al., 2013). The participants cite traditional family concepts linked to the nucleus formed by parents and children and the joint construction of a piece of work, which they used when they reflected on the course of their lives (Fonseca \& Duarte, 2014). M6 and F6, belonging to an older generation, show that they understand that the family is formed, starting from the formation of the couple, then with the arrival of their children, as Borges and Magalhães (2013) point out.

The report by $\mathrm{M} 1$ addresses the importance of admiring his partner professionally, not only for the first choice, but also for the resumption of the marital relationship, suggesting the need for security and a planned life. This indicates the presence of existence values, specifically related to personal stability (Gouveia, 2003), consistent with a society that values the material question and the attributes of a "hard working" person (Gomes et al., 2013).

For some participants, it was necessary to analyze how the present value of individual freedom would be appropriate, in marriage, in a new marital moment.

A commitment to affectivity, mutual goals and projects, to future projects, in fact, in common. Common life goals. ... So today I am much less selfish, I am much less bossy, and I have really learned to separate $N$., $N$. as a professional and N. as a father, a husband, an individual (M5, 45 years-old, 2 r.y.).

And I think it is to seek balance in the difficult moments that always happen, right? I think the partnership thing has to do, in marriage, with tolerance, with acceptance of the other, the way the other person deals with things. Sometimes it's very difficult. ... He continues, he is free to do his own things, as I am, and I think it's good. He keeps doing his things, playing his sports, but it's in a different way than it was at that point of separation. Nothing mattered, just what he wanted. And so, like, you can either come with me, or so long! (F5, 45 years-old, 8 r.y.).

These reports show that spouses needed to revise their beliefs about the marital process (Willoughby et al., 2015b) in order to include their husbands and children as partners in various aspects of family life, such as projects and leisure options. This indicates that both spouses should be willing to give in sometimes, so that a conjugal identity can be built (Fonseca \& Duarte, 2014). It is perceived that, although difficult, it is feasible to have a "non-hypocritical" marriage, in which it is possible to reconcile the spouses' individualities and expectations regarding marriage, without the marital bond frustrating the goals of each individual (Borges et al., 2014). It is noteworthy in F5's speech that when the inevitable difficulties of a relationship arise, partners need to seek balance to overcome the challenges together, illustrating the value given to diminishing asymmetries between the spouses (Borges \& Magalhães, 2013; Fonseca \& Duarte, 2014).

Most of the interviewees presented a concept of marriage related to the union of 'two people who complement each other' and who have a serious commitment to share a conjugal life, which is made of ups and downs.

It is a relationship of two people who complement each other, it is a complementarity relation in which these things harmonize over time. You get to the point where you accept differences in a 
positive way, and you build a more mature relationship through that acceptance and the positive things you see in each other. ... Let's put it this way, it was the way she treated me, she took me back to things I dreamed about a woman. That thing of romanticism (M2, 68 years-old, 22 r.y.).

Marriage to me is the union of souls, right? It's something so very deep. It is complicity. It's as if we made a pact of complicity, of friendship, you get it? I think even more than ... I think it's an agreement, an alliance that we make of ... 'let's be together'. ... It was a conversation without a fight, no discussion, a long talk. That moved me. I kept thinking about it, I kept thinking about the marriage, I also thought about what I wanted as a family. We do not marry to separate (F3, 36 years-old, 8 r.y.).

Marriage is, it's, it's a solidity, got it? It is a safe haven for a couple. The couple who wants to be, to have a safe haven, needs to get married because marriage to me is the restoration of everything. It's, it's, it's the sharing, it's the ... it's the living, you know? It is the division, it is the sum, it is the multiplication, it is everything. ... Today, in all sincerity, I am sure that without her I am nothing. Separation was a ... separation was a defeat. My separation, for me, was a defeat. I felt ... I was a defeated person (M3, 63 years-old, 16 r.y.).

The narratives suggest that the view of marriage as something solid or a 'covenant of complicity', which one does not intend to give up easily, reinforced the commitment between the spouses, pointing to beliefs of marital permanence (Willoughby et al., 2015b). This result is somewhat different from the findings of Borges and Magalhães (2013), since it also occurred with the younger generation. It is important to emphasize that such a lifelong commitment is not presented by the participants as a burden, but rather as a partnership in which there is complicity, companionship and emotional security (Fonseca \& Duarte, 2014; Norgren et al., 2004; Zordan et al., 2009). These aspects illustrate the personal investment in the relationship, a characteristic of the presence of beliefs of marital centrality (Willoughby et al., 2015a). It is perceived that these spouses tend to see their relationship as a synergistic union that expands their abilities, generating a feeling of completeness 'without it, I am nothing', 'union of souls', 'it is a complementarity' (Dollahite et al., 2012).

In general, the results also legitimize the existence of the interactional value of affection when choosing for the restoration and maintenance of marriage, since the participants attach great importance to true friendship, intimacy and sharing lives (Gouveia, 2003). For these people, marriage seems to have an emphasis on unity, on being very special, it is above individual fulfillment, it needs equity of roles and, despite presenting some romantic characteristics, requires investment (Hall, 2006). It is important to note that the question of romanticism does not seem to be linked to the fact that this individual has been recently remarried, since the vast majority has been remarried for many years.

\section{- Religious beliefs}

Half of the interviewees added different dimensions of religious beliefs, as part of their personal values, in explaining how the process of rebuilding the marital relationship occurred.

Because we have learned that marriage is indissoluble, and we had the influence of the church. So, we would try to hold, hold, hold it as much as possible, try to solve, solve, solve it... When we used to argue about something and I said: I'm going to bed; she would say, 'No, I'm not going to bed, no. I learned that we cannot let the sun go down and that we have to talk and solve it. 'And after we were back together, and we had the support there ... of the church, which was 
opportunity to work there and called us to do so many things with them, to everything. The Pastor came to our house with his wife (M1, 55 years-old, 20 r.y.).

A storm of things in my head. Oh, there are things that ... I do not have the strength to do. Another thing, I cannot get a hold of it. Then I remember that I wrote a letter to Jesus. Yes, Jesus! Every day was like this, I kept telling Him what was my dream ... The will to change. But I wanted Him more than I knew because I did not have the strength to do it. And I wanted to go back to my family, I wanted to rebuild my life. ... Then religion also got in, and we began to walk together. We did the seminar for married couples, we began to work in the church ministry, began to work in the Marian movement, then we began to pray together ( $M 2,68$ years-old, 22 r.y.).

Today I know it's the small cracks that sink a boat, right? That at the time I didn't care because I did not have Jesus in my life; so I let those cracks be. Until after two and a half years, we were invited three times to a married couples seminar, and I denied it two times. The third time they invited me, I was already seeing that things were bad and I said: 'my marriage will never work again. C. will ask me out again...' Then I said: 'C., I want to go to the seminar for married couples'. That's when I went and made the biggest decision of my life - I accepted Jesus (M3, 63 years-old, 16 r.y.)

The reports point to the value of marriage as something sacred and strongly linked to the faith of these people (Fonseca \& Duarte, 2014; Zordan et al., 2009). Having the same religious orientation was one factor that seems to have helped the spouses to succeed in reconciliation, insofar as it strengthened marital bonds. M3 cites that his conversion to his wife's religion was a fundamental decision for the redirection of his life, at a time when a new separation was imminent (Ciscon-Evangelista \& Menandro, 2011; Norgren et al., 2004). The commitment of the partners can also be exemplified by M1's narrative regarding the couple's willingness to exhaust all possibilities of conflict resolution, acting as a protector of his marriage (Ciscon-Evangelista \& Menandro, 2011; Olson et al., 2015). It is thus perceived that the accounts illustrate the question of the indissolubility of marriage under the bias of trust in religious beliefs, which presuppose that it is composed of vows that cannot be undone (Dollahite et al., 2012; Ellison et al., 2013; Goodman et al., 2013).

The interviewees mentioned the participation of both spouses in various religious activities, such as church ministry work, married couples' seminars, and meetings with religious leaders. One can notice a context in which their regular practice reinforced the internalization of the reasonableness of the system of beliefs and values associated with the doctrines of the institutions to which they were linked, which encouraged them to maintain their marriage (Burdette et al., 2007; Ellison et al., 2013, Olson et al., 2013). It is also noted that the support of a community of faith, as exemplified by $M 1$, operated as one more factor contributing to the consolidation of the relationship between the partners (Dollahite et al., 2012; Goodman et al., 2013).

As M2, other participants reported their belief in God and seeking intimacy with Him to make the changes they needed, to rebuild their lives, and to keep their commitment (Dollahite et al., 2012).

And I began to pray and I sought God a lot, I prayed a lot, and I prayed for the Lord's help. And I, as always, kept believing that God could do it, God could do it! And I had that will. ... So, as a Christian, I've learned that God uses strange ways for us ... to be able to show us certain things, to mature us. And there is no other way to mature that does not involve suffering, unfortunately. And today I see it like this: 'No, gosh, I think I got over it, I got over it. With God's help, of course! (F3, 36 years-old, 8 r.y.).

I got to know Jesus better, okay? Then, I read the Bible and I said "oh God, show me the right way because this life is wrong for me. I do not want to live wrong ...". And also in Ecclesiastes 7, I understood that I should go back to the wife of my youth. So I put that in my head, huh? I married her again. First I prayed to God. Since I want to live my life in the way of the Lord, I have to do the right thing, right? That's where I opened the Bible, suddenly there was that part, which I began 
to read, and the answer was clear. ... I became more responsible in my life. Became a more loving person. And to have more knowledge of ... God. Of peace. And furthermore, the word of God that helped me a lot, right? (M4, 76 years-old, 6 a.m.).

And after we came back... we found out that, before God, I mean ... we married in the synagogue, we had not separated ... We did not remember ... So, it was written, it doesn't matter, maktub, there is no way, we did not separate before God.... And so, because there is one thing in my life that, kind of, God's always given me a second chance (F6, 65 years-old, 18 r.y.).

The interviewees engaged in non-institutional devotional activities, such as prayer and Bible reading, to seek God's help and wisdom to deal with the challenges of the marital relationship. The speech by F3 suggests that the intensification of individual prayer strengthened commitment to the belief that God could intervene in the situation and change the course of her remarriage, since her first marriage had been quite stressful (Ellison et al., 2013; Olson et al., 2015). Religious beliefs also appeared to be fundamental to the spouses in the perception and coping with difficulties, insofar as they understand that adverse situations have a divine intention, whose ultimate product is maturity through overcoming suffering (Goodman et al., 2013).

Some participants, such as M4, mentioned that reading the Scriptures helped them to connect with God, to be better people, and showed them the way forward (Goodman et al., 2013). This suggests that the effective reinforcement of conservative doctrines is related to behavioral changes, as pointed out by Burdette et al. (2007). The search for M4 by a clear answer from God, through the Bible, because he wanted to 'do the right thing', indicates that it is important that a sincere conviction, coming from within, precedes the specific attitude towards reconciliation (Dollahite et al., 2012). Another interesting point is the role of rituals for these people. F6, for example, even though she is a Buddhist now, believes that because they were married in the synagogue, since they are of Jewish origin, they had not separated; and because of this, God gave her 'a second chance'. Such a fact suggests the existence of the belief that their marriage would have to serve a purpose greater than the couple's longings and, therefore, God would not have allowed the separation to be definitive (Goodman et al., 2013).

It is observed that, consistently, interviewees who attach greater importance to religious beliefs have normative values associated with honesty, obedience and tradition, since they show that they give importance to their vows, to the fulfillment of their duties and to the respect of cultural standards (Gouveia, 2003). For these people, God seems to have a central role in marriage - being a perfect parental figure to be subjected to, and who provides the necessary strength, security, direction, and skills for a peaceful and fulfilling relationship. His lines suggest that God's perception as a moral authority brought about behavioral changes that led to a more fulfilling marital relationship (Shichida et al., 2015).

It is relevant to mention that the participants tended to give more answers related to overcoming situations, although they were questioned about the pros and cons of remarriage - losses and gains, expectations met or not, positive and negative changes. Perhaps, to some extent to some individuals, there has been a need to report more emphatically what they considered politically correct. In any case, it is worth remembering that the focus of this research is in the aspects that contributed to the reconciliation process, not the questions that still need to be improved, mentioned with less emphasis by the interviewees.

\section{Final Considerations}

The results of this study indicate that the personal values, associated with what marriage represents, are part of the foundation that supports the chosen direction for the reconstruction of the affective life after marital separation. These values seem to have subsidized part of the basis upon which the participants solidified the decision for reconciliation. As they followed the ways they decided to take in their married lives, 
the participants, aware of what they valued most and the associated investments, reported experiencing pleasant sensations such as peace, harmony and security, which facilitated the consolidation of this process. The narratives suggest that this group of people has a traditional system of values and that emphasizes marriage as a relationship that requires a lot of investment, but which generates rewarding results as a consequence.

Interviewees focused less on the individuality and more in marriage as a special dimension, which contributed to a greater unity between the spouses and a greater commitment to avoid a new separation. In only one case, the values related to personal stability were perceived, suggesting that these are not the most relevant for reconciliation. On the other hand, affectivity was observed as an important value and there is a great appreciation of intimacy, complicity, partnership, companionship and synergy resulting from the complementarity between the partners, illustrating the centrality of the role of the spouse in the lives of these people.

The data show that when there are beliefs of marital permanence, such as believing that marriage can only be broken in extreme cases, spouses are encouraged to invest more in solving problems and overcoming challenges together. When there is this long-term commitment, partners tend to seek various alternatives for conflict resolution through dialogue, mutual acceptance and willingness to give in, subordinating a personal position to what is best for the relationship.

Those who are most touched by religious beliefs seem to trust that God, even being a supreme being, is accessible and present in their daily lives to give directions on how to deal with difficult situations, thus causing a stabilizing effect on marriage. In this sense, these people use religious resources such as praying, Bible reading, counseling with church leaders, meetings and seminars of various kinds, and community support to help them reflect on another point of view and transform their way of living and relating to one another. To the extent that they were successful in facing adversity and overcoming obstacles, by relying on these resources regularly, participants were able to confirm that their beliefs were valid and that this was a fruitful path to personal maturity throughout life.

Sharing the same beliefs, focused on more conservative doctrines such as obedience and tradition, seems to facilitate the reinforcement of the marital commitment of the more religious individuals, insofar as they believe that their marriage has a greater purpose than just meeting their own needs. The reports indicate that the change of these people in relation to the relationship with the former spouse happened before, sincerely, in their hearts, from an honest search of intimacy with God, to later be externalized in actions. In this way, it is noticed how God, as a model to be followed and as a provider of several needs, becomes crucial for the reconstruction of the conjugal relationship of spouses that emphasized the different dimensions of religious beliefs.

This study points to the question that more traditional values, which consider the institutional characteristics of marriage, coexist with contemporary models of relationships and can sustain the restoration of broken relationships in a rewarding way, and not only for religious individuals. The results, therefore, appear as a counterpoint to the current dominant discourse of valorization of the individual over the collective, regarding marital relations. The information contained in this study may stimulate couple psychotherapists to consider these issues, generating a broader view of the dyad and other aspects with a good chance of motivating a change in relationships.

This research has some limitations. It would be desirable to have extended the minimum duration for the separation period and the period for remarriage, seeking a greater homogenization of the group of participants. However, the fact that remarriage with the same spouse was an infrequent phenomenon did not allow the application of this criterion. The study was performed with independent members of remarried couples, that is, men and women from different couples; however, if it had focused on couples, it could favor a deeper reflection on the conjugal dynamics that led to reconciliation. In addition, because it is a topic 
with scarce specific literature, in the discussion of the data obtained in this study, it was necessary to include studies on love relations in general, and not just the ones focused on remarriage.

Further research could analyze, in more detail, how each of the aforementioned dimensions of religiosity had repercussions on the consolidation of the relationship with the ex-spouse over the years. It could also be verified if the differences between the age groups of the participants affect the personal values associated with the marriage. Yet, other factors could be investigated, besides the personal values, that have been considered as ingredients of the foundation that sustained the reconciliation, seeking to broaden the understanding on the subject.

\section{Contributors}

M.I.C.A. LIMEIRA elaborated the article, from her doctoral thesis, for which she analyzed and interpreted interview data. T. FÉRES-CARNEIRO was the doctoral advisor, monitored the design and elaboration of the article, and performed its general review

\section{References}

Alves-Silva, J. D., Scorsolini-Comin, F., \& dos Santos, M. A. (2016). Conjugalidade e casamentos de longa duração na literatura científica. Contextos Clínicos, 9(1), 32-50. http://dx.doi.org/10.4013/ctc.2016.91.03

Bardin, L. (2011). Análise de conteúdo. São Paulo: Edições 70.

Barret, R. (2000). Libertando a alma da empresa. São Paulo: Cultrix.

Borges, C. C., \& Magalhães, A. S. (2013). Individualism, life trajectories and plans of constituting a family. Estudos de Psicologia (Campinas), 30(2), 177-185. http://dx.doi.org/10.1590/S0103-166X2013000200004

Borges, C. C., Magalhães, A. S., \& Féres-Carneiro, T. (2014). Liberdade e desejo de constituir família: percepções de jovens adultos. Arquivos Brasileiros de Psicologia, 66(3), 89-103. Recuperado em setembro 7, 2017, de http://pepsic. bvsalud.org/scielo.php?script=sci_arttext\&pid=S1809-52672014000300008\&lng=pt\&tlng=pt

Burdette, A. M., Ellison, C. G., Sherkat, D. E., \& Gore, K. A. (2007). Are there religious variations in marital infidelity? Journal of Family Issues, 28(12), 1553-1581. https://dx.doi.org/10.1177/0192513X07304269

Ciscon-Evangelista, M. R., \& Menandro, P. R. M. (2011). Casados para sempre: casamento e família na concepção de casais evangélicos neopentecostais. Psicologia Argumento, 29(66), 343-352. Recuperado em novembro 10, 2017 de https://periodicos.pucpr.br/index.php/psicologiaargumento/article/view/20343/19613

Dollahite, D. C., Hawkins, A. J., \& Parr, M. R. (2012). "Something More": The meanings of marriage for religious couples in America. Marriage \& Family Review, 48(4), 339-362. http://dx.doi.org/10.1080/01494929.2012.674480

Ellison, C. G., Wolfinger, N. H., \& Ramos-Wada, A. I. (2013). Attitudes toward marriage, divorce, cohabitation, and casual sex among working-age Latinos: Does religion matter? Journal of Family Issues, 34(3), 295-322. http://dx. doi. org/10.1177/0192513X12445458

Fonseca, S. R. A., \& Duarte, C. M. N. (2014). Do namoro ao casamento: significados, expectativas, conflito e amor. Psicologia: Teoria e Pesquisa, 30(2), 135-143. http://dx.doi.org/10.1590/\$0102-37722014000200002

Gomes, A. I. A. S. B., Gouveia, V. V., Silva Júnior, N. A., Coutinho, M. L., \& Campos, L. C. de O. (2013). Escolha do (a) parceiro (a) ideal por heterossexuais: são seus valores e traços de personalidade uma explicação? Psicologia: Reflexão e Crítica, 26(1), 29-37. http://dx.doi.org/10.1590/50102-79722013000100004

Goodman, M. A., Dollahite, D. C., Marks, L. D., \& Layton, E. (2013). Religious faith and transformational processes in marriage: Transformational processes and religious faith. Family Relations, 62(5), 808-823. http://dx.doi.org/10.1111/ fare. 12038

Gouveia, V. V. (2003). A natureza motivacional dos valores humanos: evidências acerca de uma nova tipologia. Estudos de Psicologia, 8(3), 431-443.

Hall, S. S. (2006). Marital meaning: exploring young adults' belief systems about marriage. Journal of Family Issues, 27(10), 1437-1458. http://dx.doi.org/10.1177/0192513X06290036 
Lloyd, G. M., Sailor, J. L., \& Carney, W. (2014). A Phenomenological study of postdivorce adjustment in midlife. Journal of Divorce \& Remarriage, 55(6), 441-450. http://dx. doi.org/10.1080/10502556.2014.931757

Maslow, A. H. (1943). A theory of human motivation. Psychological Review, 50(4), 370-396. http://dx.doi.org/10.1037/ h0054346

Minayo, M. C. S. (2017). Amostragem e saturação em pesquisa qualitativa: consensos e controvérsias. Revista Pesquisa Qualitativa, 22(7), 1-12. Recuperado em fevereiro 25, 2019 de https://www.researchgate.net/publication/315756131

Norgren, M. B. P., Souza, R. M., Kaslow, F., Hammerschmidt, H., \& Sharlin, S. A. (2004). Satisfação conjugal em casamentos de longa duração: uma construção possível. Estudos de Psicologia, 9(3), 575-584. http://dx.doi.org/10.1590/S1413294X2004000300020

Olson, J. R., Goddard, H. W., \& Marshall, J. P. (2013). Relations among risk, religiosity, and marital commitment. Journal of Couple \& Relationship Therapy, 12(3), 235-254. http://dx.doi.org/10.1080/15332691.2013.806705

Olson, J. R., Marshall, J. P., Goddard, H. W., \& Schramm, D. G. (2015). Shared religious beliefs, prayer, and forgiveness as predictors of marital satisfaction: Religiosity and marital satisfaction. Family Relations, 64(4), 519-533. http://dx.doi. org/10.1111/fare.12129

Shichida, T., Dollahite, D. C., \& Carroll, J. S. (2015). How the perception of God as a transcendent moral authority influences marital connection among American Christians. Journal of Psychology and Christianity, 34(1), 40-52. Retrieved May 12, 2017, from https://www.thefreelibrary.com/How the perception of God as a transcendent moral authority...-a0410904949

Wilcox, W. B., \& Dew, J. (2016). The social and cultural predictors of generosity in marriage gender egalitarianism, religiosity, and familism. Journal of Family Issues, 37(1), 97-118. http://dx.doi.org/10.1177/0192513X13513581

Willoughby, B. J., Hall, S. S., \& Goff, S. (2015a). Marriage matters but how much: Marital centrality among young adults. The Journal of Psychology, 149(8), 796-817. http://dx.doi.org/10.1080/00223980.2014.979128

Willoughby, B. J., Hall, S. S., \& Luczak, H. P. (2015b). Marital paradigms: A conceptual framework for marital attitudes, values, and beliefs. Journal of Family Issues, 36(2), 188-211. http://dx.doi.org/10.1177\%2F0192513X13487677

Zordan, E. P., Falcke, D., \& Wagner, A. (2009). Casar ou não casar: motivos e expectativas com relação ao casamento. Psicologia em Revista, 15(2), 56-76. Recuperado em março 14, 2017, de http://pepsic.bvsalud.org/scielo.php?script=sci_ arttext\&pid=S1677-11682009000200005\&lng=pt\&tlng=pt

Received: September 18, 2018

Final version: March 27, 2019

Approved: May 31, 2019 